Gi respons på artikler gjennom artiklenes kommentarfelt på tidsskriftet.no.

Innleggene publiseres fortløpende på Tidsskriftets nettside og et utvalg

av innleggene publiseres også i papirutgaven i spalten «Brev til redaktøren».

Redaksjonen forbeholder seg retten til å foreta redaksjonelle endringer.

Forfattere av vitenskapelige artikler har tilsvarsrett, jf. Vancouver-gruppens regler.

\section{Re: Ebola er ikke Sierra Leones største problem}

Takk til forfatterne for en interessant artikkel i Tidsskriftet nr. 23-24/ 2015 om helseutfordringene i Sierra Leone (1). Mange, både nasjonale og utenlandske helsearbeidere, gjorde en fantastisk innsats mot ebola. Men det er tankevekkende at det kanskje var de forholdsvis få sykdomstilfellene blant internasjonale helsearbeidere, og potensialet for smitte til vestlige land, som bidro mest til den massive hjelpen som ble gitt etter hvert.

Som forfatterne påpeker, var dårlig utbygde nasjonale helsesystemer i de aktuelle landene antagelig den viktigste årsaken til at epidemien ble så alvorlig.

Helsesystemer bygges ikke over natten. I årene fra 1972 til 1996 ga Norge betydelig støtte til utvikling av primærhelsetjenesten i Botswana. Det ble satset på utbygging av infrastruktur (helseposter, klinikker og boliger for helsepersonell) på landsbygda og det ble gitt personellstøtte, særlig til distriktshelseteam. I tillegg bidro Norge til å bygge opp et robust system for innkjøp og distribusjon av legemidler og til utvikling av tannhelsetjeneste.

Primærhelsetjenesten i Botswana regnes for en av de beste i Afrika. Selv om dette kan tilskrives flere forhold, ikke minst en god økonomisk utvikling, mener mange at det norske bidraget var vesentlig. Vi snakker da om en vid tilnærming gjennom mer enn 20 år (2).

Norge bidrar med store summer til det Globale fondet og til den globale vaksinealliansen. Men kunne vi ikke også gjøre noe lignende i Sierra Leone som vi gjorde i Botswana?

\section{Tore Wælgaard Steen}

torewsteen@hotmail.com

Tore W Steen (f. 1950) er smittevernoverlege i Helseetaten, Oslo kommune.

Ingen oppgitte interessekonflikter.

\footnotetext{
Litteratur

1. Tranvåg EJ, Onarheim KH. Ebola er ikke Sierra Leones største problem. Tidsskr Nor Legeforen 2015; 135: 2192-3.

2. Evaluation of Norwegian health sector support to Botswana. Report 10/2011. Oslo: Norad, 2012
}

\section{E.J. Tranvåg \& K.H. Onarheim svarer:}

Vi vil takke Tore Wælgaard Steen for positiv respons på og refleksjoner rundt vår artikkel. Norads evaluering av Norges langsiktige støtte til oppbyggingen av primærhelsetjenesten i Botswana er et interessant eksempel på hvordan historien kan lære oss mye (1). Tidligere erfaringer fra Botswana og fra dagens ebola-diskusjoner er viktige når vi ønsker å forbedre dagens og fremtidens helsesystemer. En rapport nylig publisert i The Lancet fremhever store mangler i nasjonale og internasjonale institusjoner med ansvar for å forebygge, oppdage og respondere på slike utbrudd (2).

Men som vi skriver i artikkelen vår, respons på sykdomsutbrudd må regnes som en bonus - og bare en del av oppgavene til et sterkt og godt fungerende helsesystem. Land må ha muligheten til å forebygge og behandle de sykdommene som er tilstede her og nå, i tillegg til å sikre seg mot fremtidige trusler. I løpet av de siste 96 dagene av 2015, fra den siste ebola-pasienten testet negativt i Sierra Leone 26.09.15 (3) og ut året, har malaria og luftveisinfeksjoner tatt flere liv enn det ebolaviruset gjorde under hele epidemien (egne kalkulasjoner, basert på (4)). Nettopp derfor må prioriteringene våre styres av gode og rettferdige kriterier.
I et nylig publiserte notatet fra Civita om norsk helsebistand bemerkes det at «[det] er ingen vei til bærekraftig bedring av folkehelse utenom nasjonale systemer og nasjonalt eierskap.» (5) De peker også på Norges sterke økonomi og oppslutning rundt bistand og mulighetene dette gir til å fokusere på blant annet helsesystemer. Vi er enig i dette og mener Norge bør prioritere satsning på helsesystemer høyere enn i dag.

\section{Eirik Joakim Tranvåg}

eirik.tranvag@uib.no

Kristine Husøy Onarheim

Eirik Joakim Tranvåg (f. 1984) er lege og jobber i forskningsgruppen Globale helseprioriteringer ved Institutt for global helse og samfunnsmedisin, Universitetet i Bergen.

Ingen oppgitte interessekonflikter.

Kristine Husøy Onarheim (f. 1987) er lege og ph.d.-student i forskningsgruppen Globale helseprioriteringer ved Institutt for global helse og samfunnsmedisin, Universitetet i Bergen.

Ingen oppgitte interessekonflikter.

Litteratur

1. Evaluation of Norwegian health sector support to Botswana. Report 10/2011. Oslo: Norad, 2012

2. Moon S, Sridhar D, Pate MA et al. Will Ebola change the game? Ten essential reforms before the next pandemic. The report of the Harvard-LSHTM Independent Panel on the Global Response to Ebola. Lancet 2015; 386: 2204-21.

3. 2014 Ebola Outbreak in West Africa - Case Counts. www.cdc.gov/vhf/ebola/ outbreaks/2014-west-africa/case-counts.html (21.12. 2015).

4. Helleringer S, Noymer A. Magnitude of Ebola relative to other causes of death in Liberia, Sierra Leone, and Guinea. Lancet Glob Health 2015; 3: e255-6.

5. Hegertun N. Wihelmsen SR. Civita-notat $31 / 2015$ «Norsk helsebistand: fra helseklinikk til global politikk. www.civita.no/publikasjon/

nr-31-norsk-helsebistand-fra-helseklinikk-til-global-politikk (18.1.2016).

\section{Re: Kronisk utmattelsessyndrom/myalgisk encefalopati - sykdomsmekanismer, diagnostikk og behandling}

Retorisk utmattelsessyndrom. Det er synd at debatten om kronisk utmattelsessyndrom/myalgisk encefalopati er så betent at en kronikk om sykdomsmekanismer, diagnostikk og behandling i Tidsskriftet nr. 23-24/2015 munner ut i en høystemt hyllest av sannheten som man tilsynelatende selv mener å ha et ganske godt grep om (1). Dette i motsetning til synsende meningsmotstandere som mangler kompetanse og etisk standard, og som farer med retorikk og «vitenskapelig abdikasjon». Abdikasjon betyr å si fra seg embete eller verdighet, og brukes gjerne om monarker. Vi snakker med andre ord om knall og fall og retorikk på svært høyt nivå. Denne høyden er neppe et fjell av solid empirisk kunnskap, noe det ser ut til å være lite av ved denne gåtefulle tilstanden.

Jeg har ingenting imot Wyller og medarbeideres modell for forståelse av kronisk utmattelsessyndrom/myalgisk encefalopati, som integrerer psyke og soma. Et problem kan imidlertid være at en slik forklaringsmodell vanskelig lar seg teste som en vitenskapelig hypotese. Enten man finner eller ikke finner biologiske forandringer er det like forenlig med forklaringsmodellen.

Redaktør Are Brean skriver at skillet mellom «psykisk» og «fysisk» står i veien for en integrert forståelse av mennesket (2).

Det kan man vanskelig være uenig i. Erfaringer som oppdagelsene av Helicobacter pylori ved magesår, NMDA-reseptorantistoffer ved 
autoimmun encefalitt og Borrelia burgdorferi ved nevroborreliose har imidlertid vist at rent fysiske forklaringer kan være til større nytte for pasienten. Disse erfaringene har også vist at vi må være åpne for stadig å endre vår virkelighetsforståelse, og at det kan være skummelt å forklare sykdommer vi ikke forstår med pasientens personlighet, som er en av boksene i Wyller og medarbeideres modell.

Påstanden om at det å ha slektninger med den aktuelle diagnosen er en interessekonflikt, er nå blitt fremsatt flere ganger. Det forbauser meg at man ikke i større grad ønsker forskning og engasjement, også på tvers av egne hypoteser, velkommen i større grad. Det kan virke som om det er investert så mye faglig prestisje at sannheten, hva den måtte vise seg å være, bør søke asyl andre steder enn i Tidsskriftets spalter.

\section{Trygve Holmøy}

trygve.holmoy@medisin.uio.no

Trygve Holmøy (f. 1960) er overlege og professor ved Nevroklinikken, Akershus universitetssykehus.

Ingen oppgitte interessekonflikter

\section{Litteratur \\ 1. Wyller VB, Reme SE, Mollnes TE. Kronisk utmattelsessyndrom/myalgisk ence- falopati - sykdomsmekanismer, diagnostikk og behandling. Tidsskr Nor Lege- foren 2015: 135: 2172-5. \\ 2. Brean A. Bare psykisk. Tidsskr Nor Legeforen 2015; 135: 2127. \\ Re: Kronisk utmattelsessyndrom/myalgisk encefalopati - sykdomsmekanismer, diagnostikk og behandling}

Bruun Wyller og medarbeidere oppsummerer i Tidsskriftet sin forståelse av myalgisk encefalopati (ME) som en vedvarende stressrespons (1). Kronikken må forstås som en kommentar til Egeland og medarbeidere om ME hvor vi oppsummerer internasjonal status for sykdomsforståelsen (2). Den største synteserapporten som foreligger, fra Institute of Medicine i USA, slår klart fast at ME er en biomedisinsk sykdom (3). Det er denne rapporten Bruun Wyller og medarbeidere burde kommentere hvis de er uenig i konklusjonene våre, i stedet for å bruke flere avsnitt på å karakterisere andre deltagere i ME debatten. Rapporten kan sees som et oppgjør med bl.a. Bruun Wyllers syn på ME.

Bruun Wyllers gjennomgang av litteraturen er mangelfull. En ny studie av Horning og medarbeidere viser at cytokinprofilen endres over tid med sykdomsforløpet til ME-pasienter (4). I Bruun Wyllers egen studie og den refererte meta-analysen er denne tidsfaktoren utelatt. En fersk studie viser at isolerte muskelceller fra ME pasienter responderer annerledes på fysisk stress enn friske kontroller, blant annet ved å ikke ta opp glukose (5). Nylig påviste Loebel og medarbeidere (6) forhøyede antistoffer i serum mot $\beta$-adrenerge og muskarin-kolinerge reseptorer hos ME pasienter. Og hvorfor ønsker Bruun Wyller å tone ned betydningen av den lovende Rituximab studien på Haukeland, som trekker i retning av at ME er en autoimmun sykdom?

Studiene om effekten av kognitiv adferdsterapi ved ME er lite overbevisende. PACE studien, som Bruun Wyller oftest refererer til, viser ikke at kognitiv adferdsterapi har bedre effekt enn andre behandlinger, inkludert aktivitetstilpasning. Ved for eksempel $6 \mathrm{~min}$ gangtest gir kognitiv adferdsterapi behandling en økning på 20 meter i forhold til aktivitetstilpasning, men fortsatt er pasientgruppen på et svært lavt funksjonsnivå (7). Det er i tillegg en rekke alvorlige metodiske svakheter med PACE studien. I tillegg rapporterer mange pasienter at de blir dårligere av kognitiv adferdsterapi.

Bruun Wyller og medarbeidere misliker at noen «i vitenskapelige toppstillinger uttaler seg med skråsikkerhet om et fagområde de verken har klinisk eller vitenskapelig erfaring fra». Jeg har engasjert meg for ME pasientene fordi jeg har sett hvor dårlig mange av dem behandles. Jeg har i flere år reist rundt $\mathrm{i}$ hele landet og besøkt mange av de sykeste pasientene hjemme eller på sykehjem. Mange av dem faller utenfor helsevesenets tilbud. Jeg har jevnlig deltatt på internasjonale $\mathrm{ME}$ kongresser de siste 20 årene.

Bruun Wyller og medarbeideres syn på ME representerer gårsdagens forståelse og er slik sett av liten interesse. Problemet er at denne forståelsen har bidratt til manglende utredning og dårlige og misforståtte behandlinger av svært syke pasienter.

\section{Ola Didrik Saugstad}

odsaugstad@rr-research.no

Ola Didrik Saugstad (f. 1947) er professor ved Pediatrisk forskningsinstitutt, Universitetet i Oslo og Oslo universitetssykehus.

Ingen oppgitte interessekonflikter.

\section{Litteratur}

1. Wyller VB, Reme SE, Mollnes TE. Kronisk utmattelsessyndrom/myalgisk encefalopati - sykdomsmekanismer, diagnostikk og behandling. Tidsskr Nor Legeforen 2015; 135: 2172-5

2. Egeland T, Angelsen A, Haug R et al. Hva er egentlig Myaligisk encepalopati? Tidsskr Nor Legeforen 2015: 135: 1756-9.

3. Committee on the Diagnostic Criteria for Myalgic Encephalomyelitis/Chronic Fatigue Syndrome; Board on the Health of Select Populations. Institute of Medicine. Beyond myalgic encephalomyelitis/chronic fatigue syndrome: redefining an illness. Washington, DC: The National Academies Press, 2015.

4. Hornig M, Montoya JG, Klimas NG et al. Distinct plasma immune signatures in ME/CFS are present early in the course of illness. Sci Adv 2015; 1: e1400121.

5. Brown AE, Jones DE, Walker $M$ et al. Abnormalities of AMPK activation and glucose uptake in cultured skeletal muscle cells from individuals with chronic fatigue syndrome. PLoS ONE 2015: 10: e0122982.

6. Loebel M, Grabowski P. Heidecke $H$ et al. Antibodies to $\beta$ adrenergic and muscarinic cholinergic receptors in patients with Chronic Fatigue Syndrome. Brain Behav Immun 2016; 52: 32-9.

7. White PD, Goldsmith KA, Johnson AL et al; PACE trial management group. Comparison of adaptive pacing therapy, cognitive behaviour therapy, graded exercise therapy, and specialist medical care for chronic fatigue syndrome (PACE): a randomised trial. Lancet 2011; 377: 823-36.

\section{Re: Mutasjon hos barn kan gi høy risiko for arvelig Alzheimers sykdom}

Jeg viser til Tidsskiftet nr. 21/2015, hvor en artikkel fra Jama Neurology omtales (1). Artikkelen er antakelig solid, og dette temaet kan jeg minimalt om, men til tross for min manglende kjennskap til feltet, må jeg likevel peke på en bekymring. Det dreier seg altså om en gruppe barn i aldersgruppen 9-17 år som får påvist en mutasjon som med nær $100 \%$ sannsynlighet gir Alzheimers sykdom med tidlig debut (median symptomdebut ved 44 års alder). Det jeg stiller spørsmål ved er om det er etisk riktig at barn her har fått utført gentesten. De vokser altså opp med en visshet om at de vil bli syke allerede fra før tenårene, uten å ha fått ta valget selv. Og det for en sykdom vi ikke har kurativ behandling for. Til sammenlikning ser jeg av norske retningslinjer at det for Huntingtons sykdom som hovedregel ikke gjøres presymptomatisk genetisk testing på barn under18 år (2). For ordens skyld: Min bekymring her handler ikke om genetisk testing per se, men altså om barn og samtykke i en slik sammenheng. Den omtalte studien kan antakelig forsvares, og kanskje er det sånn at målet helliger middelet (?), men mitt hovedankepunkt er imidlertid at dilemmaet ikke engang diskuteres, verken i artikkelen eller i Tidsskriftets omtale av den.

\section{Mari Jetlund}

marijetlund@hotmail.com

Mari Jetlund (f. 1985) er lege i spesialisering.

Ingen oppgitte interessekonflikter.

\section{Litteratur}

1. Rosness T. Mutasjon hos barn kan gi høy risiko for arvelig Alzheimers sykdom. Tidsskr Nor Legeforen 2015; 135: 1935

2. Et vanskelig valg - Huntingtons sykdom. Oslo universitetssykehus www.sjeldnediagnoser.no/docs/PDF/10_Et\%20vanskelig\%20valg_HS.pdf (21.12.2015) 